Efek Anti Angiogenesis Temu Kunci....., Noor, Erma, Sitarina, Hady

\title{
EFEK ANTI ANGIOGENESIS \\ TEMU KUNCI (Boesenbergia pandurata , (Roxb.) Schlecht) \\ PADA MEMBRAN KORIO ALANTOIS \\ EMBRIO AYAM YANG DIINDUKSI BASIC FIBROBLAST GROWTH FACTOR (bFGF)
}

\author{
Noor Ardhi Pratomo ${ }^{1}$, Erma Yunita ${ }^{1}$, Sitarina Widyarini², Hady Anshory ${ }^{1}$ \\ Program Studi Farmasi Universitas Islam Indonesia ${ }^{1}$ \\ Fakultas Kedokteran Hewan Universitas Gadjah Mada²
}

\begin{abstract}
ABSTRAK
Pertumbuhan kanker dipengaruhi oleh beberapa faktor salah satunya adalah angiogenesis. Penelitian ini bertujuan untuk mengetahui aktif tas anti kanker dari ekstrak $n$-heksan, etil asetat dan isolat pinostrobin dari rimpang temu kunci sebagai anti-angiogenesis pada membran korio alantois (CAM) embrio ayam yang diinduksi bFGF. Serbuk kering temu kunci dimaserasi menggunakan pelarut n-heksan dan etil asetat, ekstrak kemudian dipekatkan. Pinostrobin diisolasi dari ekstrak etil asetat dengan kromatograf cair vakum menggunakan gradient pelarut $n$-heksan:etil asetat, fraksi terbaik diambil untuk dilanjutkan dengan KLT preparatif. Hasil isolat diidentif kasi menggunakan KLT Densitometri dengan pembanding standar pinostrobin. Nilai panjang gelombang maksimum dari isolat dan standar pinostrobin masing-masing adalah $298 \mathrm{~nm}$ dan 299 $n$ m. Uji anti angiogenik dilakukan pada telur berembrio umur 8-9 hari yang dibagi dalam dua belas kelompok perlakuan. kelompok kontrol dan perlakuan. Kelompok kontrol terdiri dari kelompok I (paper disc), kelompok II (bFGF), dan kelompok III (bFGF + 0,8 \% DMSO). Kelompok perlakuan terdiri dari kelompok IV (n-heksana $15 \mathrm{ug} / \mathrm{ml})$, kelompok V (n-heksana $30 \mathrm{ug} / \mathrm{ml})$, kelompok VI (n-heksana $60 \mathrm{ug} / \mathrm{ml}$ ), kelompok VII (etil asetat $15 \mathrm{mg} / \mathrm{ml}$ ), golongan VIII (etil asetat $30 \mathrm{mg} / \mathrm{ml}$ ), kelompok IX (etil asetat $60 \mathrm{mg} / \mathrm{ml}$ ), kelompok $X$ (pinostrobin $10 \mathrm{nM}$ ), kelompok XI (pinostrobin $100 \mathrm{nM}$ ), kelompok XII (pinostrobin $1000 \mathrm{nM}$ ). Setelah diinkubasi selama 3 hari pada suhu $38,5^{\circ} \mathrm{C}$, telur dibuka dan isi telur dikeluarkan, kemudian membran korioallantois yang melekat pada cangkang diamati secara makroskopik dan mikroskopik menggunakan antibodi VEGF. Pengamatan makroskopis menunjukkan bahwa pinostrobin memiliki efek anti angiogenesis dengan persentase daya hambatangiogenesis yang semakin tinggi seiring peningkatan dosis sedangkan pengamatan mikroskopis menunjukkan adanya sel endotel yang terekspresi oleh VEGF pada kelompok etil asetat dan
\end{abstract}


isolat pinostrobin. Hasil ini menunjukkan bahwa ekstrak n-heksan, etil asetat dan isolat pinostrobin memiliki efek sebagai anti angiogenesis melalui jalur penghambatan $b F G F$, sedangkan yang menghambat angiogenesis melalui jalur penghambatan VEGF hanya pada kelompok etil asetat dan isolat pinostrobin.

Kata kunci : Boesenbergia pandurata (Roxb.) , ekstrak n - heksan, ekstrak etil asetat, isolat pinostrobin, antiangiogenic, CAM.

\section{PENDAHULUAN}

Penyakit kanker saat ini masih menjadi masalah serius bagi kesehatan di dunia. Dari tahun ke tahun epidemologi penyakit ini terus meningkat seiring perkembangan zaman. Kejadian kanker secara keseluruhan di antara anak usia 0-14 tahun meningkat $0,5 \%$ per tahun dan di antara anak-anak usia 0-19 tahun kejadian meningkat $0,6 \%$ per tahun 1999-2008 ${ }^{(1)}$.

Anti angiogenesis merupakan startegi yang menjanjikan untuk terapi kanker ${ }^{(2)}$. Terapi anti angiogenesis bertujuan untuk menghentikan pembentukan pembuluh darah baru sehingga seltumoratau selkankerakan mati. Angiogenesis normal terjadi di dalam tubuh, misal saat penyembuhan luka dan perbaikan jaringan tubuh yang rusak. Tetapi pada penderita kanker, proses pembentukan pembuluh darah baru ini akan membuat tumor memiliki jaringan pembuluh darah sendiri yang akan membuatnya tumbuh dengan cepat dan ganas ${ }^{(3)}$.

Rimpang temu kunci Pandurata, (Roxb) Schlecht) secara empiris digunakan untuk mengobati beberapa penyakit seperti pembengkakan kandungan kemih serta obat infeksi alat reproduksi pada wanita. Pengujian lain secara in vitro menunjukkan bahwa temu kunci dapat meningkatkan jumlah limfosit, antibodi spesif $k$, dan dapat membunuh sel kanker(4). Dalam beberapa penelitian menyatakan bahwa kandungan senyawa pinostrobin sebagai senyawa penanda temu kunci mempunyai potensi besar sebagai senyawa anti kanker, namun efektif tasnya dalam menghambat angiogenesis belum banyak diteliti( ${ }^{4,5}$.

\section{METODE PENELITIAN}

\section{Alat}

Alat yang digunakan dalam penelitian ini antara lain: alat-alat gelas (Pyrex), lemari pengering, mesin penyerbuk (Fomac), alat maserasi, waterbath (Memert), timbangan analitik, chamber, plat kaca, micro haematocrit tubes, cawan porselen, rotari evaporator (Heidolph), autoklaf, laminar air fow, alat candling, pinset, dental driil, adaptor, karet penyedot 
udara, lampu spiritus, inkubator (Memert), mikropipet, gunting, TLC densitometer (Lamag), dan kamera digital.

\section{Bahan}

Bahan yang digunakan pada penelitian ini antara lain: simplisia rimpang temu kunci (B. Pandurata, (Roxb) Schlecht), n-heksan, etil asetat, etanol 70\% (Bratachem), etanol pa. (Merck $\left.{ }^{\circledR}\right)$, DMSO (Dimethyl Sulfoxide) $0,8 \%\left(\right.$ Merck $\left.^{\circledR}\right)$, recombinant human bFGF 1ng/ul (Sigma), membran korio alantoisdariembrioayam(Rhodelsland $R e d$ ) yang diperoleh dari UPPT Bantul Yogyakarta, paper disc steril yang berisi ampisilin, plat alumunium silika GF 60 For Thin Layer Chromatografy $\left(\right.$ MerCk $\left.^{\circledR}\right)$, bubuk silika GF 60 For TLC $\left(\right.$ MerCk $\left.^{\circledR}\right)$, larutan buffer Tris-HCl 10

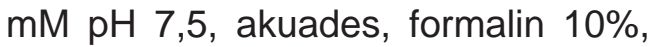
$\mathrm{NaCl} 0,9 \%$, emersi oil antibodi VEGF dan standar pinostrobin (Sigma).

\section{Metode Kerja}

\section{A. Ektraksi Temu Kunci}

Ekstraksi dilakukan dengan metode maserasi selama 2 hari menggunakan n-heksan : etil asetat sebagai pelarut dengan perbandingan jumlah pelarut 3 kali tinggi ekstrak. Serbuk simplisia dimasukkan kedalam larutan $\mathrm{n}$-heksan selama 1 hari sambil diaduk-aduk. Maserasi menggunakan $400 \mathrm{~g}$ serbuk simplisia yang dilarutkan dengan n-heksan sebanyak $950 \mathrm{~mL}$ selama 1 hari. Residu dikeringkan kemudian dimaserasi kembali dengan pelarut etil asetat selama 1 hari dengan remaserasi sebanyak 1 kali. Maserasi etil asetat awal menggunakan pelarut sebanyak $750 \mathrm{~mL}$ dan remeserasi menggunakan pelarut sebanyak 600 $\mathrm{mL}$. Hasil ekstraksi kemudian disaring terlebih dahulu dengan menggunakan penyaring Buchner kemudian disaring kembali menggunakan kertas saring. Ekstrak etil asetat dan n-heksan yang didapat berupa ekstrak semipadat.

\section{B. Isolasi Pinostrobin}

Temu kunci yang telah diserbuk di maserasi menggunakan n-heksan sebagai pelarut. Residu kemudian diekstraksi kembali dengan menggunakan pelarut etil asetat. Ekstrak etil asetat yang diperoleh dipekatkan dengan rotary evaporator untuk mendapatkan ekstrak kental.

Ekstrak kental yang didapat dipisahkan dengan kromatograf kolom menggunakan pelarut n-heksan-etilasetat $50 \mathrm{ml}$ dengan gradien konsentrasi (50:0, 45:5, $40: 10,35: 15,30: 20,25: 25,20: 30$, 15:35, 10:40, 5:45, dan 0:50). Hasil kemudian diidentif kasi menggunakan KLT dengan pembanding standar pinostorbin. Fraksi terbaik diambil untuk kemudian diisolasi dengan metode KLT preparatif, eluen yang digunakan adalah n-heksan:etil asetat (4,5:1). Spot yang sama dengan standar kemudian dikerok dan dilarutkan dengan etanol pa dan disaring. Larutan yang didapat uapkan pelarutnya hingga didapat serbuk kering. Serbuk kering yang didapat 
diidentif kasi kembali menggunakan KLT densitometri dengan pembanding standar pinostrobin untuk memastikan bahwa isolat yang didapat adalah benar pinostrobin.

\section{c. Uji Efek Anti Angiogenesis}

Preparasi bFGF sebagai induktor angiogenesis digunakan sebanyak $10 \mu \mathrm{g}$ yang dilarutkan dengan Tris- $\mathrm{HCl}$ $10 \mathrm{mM} \mathrm{pH} \mathrm{7,5} \mathrm{sehingga} \mathrm{didapat} \mathrm{kadar}$ $1 \mathrm{ng} / \mu \mathrm{l}$. Preparasi bFGF dilakukan secara aseptis di dalam LAF. Dosis bFGF yang diberikan untuk setiap telur perlakuan adalah $10 \mathrm{ng}^{(6)}$.

Bahan uji dilarutkan dengan DMSO-aquadest $0,8 \%$ steril untuk kemudian dibuat seri kadar. Preparasi dilakukan secara aseptis dalam LAF.

Telur ayam berembrio yang telah dibeli sehari sebelumnya (umur 7-8 hari (inkubasi) segera diinkubasi pada suhu $38,5^{\circ} \mathrm{C}$ agar dapat menyesuaikan diri dengan lingkungan baru. Tahap awal yaitu pemberian tanda pada kerabang telur yang meliputi batas ruang udara dan lokasi embrio. Lokasi embrio diketahui melalui candling pada telur. Kerabang telur pada bagian kutub mengandung ruang udara dan kerabang di atas embrio disterilkan dengan alkohol. Kedua daerah tersebut kemudian dibuat lubang kecil menggunakan sebuah mini drill.

Udara dari ruang udara diaspirasi dengan bola karet sampai membran korio alantois yang melekat pada telur lepas. Perlakuan ini dilakukan di ruang gelap dengan posisi telur horizontal, dan melalui candling, sehingga membran korio alantois dan ruang udara buatan yang terbentuk diatas embrio dapat terlihat. Kerabang telur diatas embrio dipotong dengan gergaji (mini drill) membuat lubang segi empat dengan luas $1 \times 1 \mathrm{~cm}$. Melalui lubang ini bFGF dan isolat diimplantasi ke dalam membran embrio alantois, setelah sebelumnya telur disterilkankan lagi dan masukkan dalam LAF dengan posisi horizontal dengan ruang udara buatan terletak dibagian atas. Subjek uji berupa telur dibagi menjadi 12 kelompok (masing-masing kelompok perlakuan terdiri dari 5 telur), sebagai berikut:

a. Kelompok I sebagai kontrol paper disc, untuk memastikan bahwa paper disc yang digunakan sebagai pembawa tidak berpengaruh pada membran korio alantois telur ayam.

b. Kelompok II adalah telur dengan implantasi paper disc yang telah

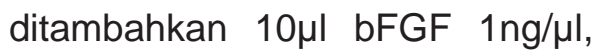
sebagai kelompok kontrol bFGF untuk melihat pengaruh induksi bFGF terhadap angiogenesis.

c. Kelompok III adalah kelompok telur dengan implantasi paper disc yang berisi $10 \mu \mathrm{l}$ bFGF $1 \mathrm{ng} / \mu \mathrm{l} \mathrm{+}$ $10 \mu$ pelarut DMSO 0,8\% sebagai kontrol bFGF + pelarut untuk mengetahui pengaruh pelarut terhadap angiogenesis pada membran korio alantois.

d. Kelompok IV, V, dan VI merupakan 
kelompok telur yang digunakan untuk melihat efek penghambatan ekstrak n-heksan terhadap angiogenesis membran korio alantois. Telur pada kelompok ini diberi implantasi dengan variasi konsentrasi $15 \mu \mathrm{g} / \mathrm{ml}, 30 \mu \mathrm{g} / \mathrm{ml}$, dan $60 \mu \mathrm{g} / \mathrm{ml}$.

e. Kelompok VII, VIII, dan IX merupakan kelompok telur yang digunakan untuk melihat efek penghambatan ekstrak etil asetat terhadap angiogenesis membran korio alantois. Telur pada kelompok ini diberi implantasi dengan variasi konsentrasi $15 \mu \mathrm{g} / \mathrm{ml}, 30 \mu \mathrm{g} / \mathrm{ml}$, dan $60 \mu \mathrm{g} / \mathrm{ml}$.

f. KelompokX, XI, dan XII merupakan kelompok telur yang digunakan untuk melihat efek penghambatan pinostrobin terhadap angiogenesis membran korio alantois. Telur pada kelompok ini diberi implantasi dengan variasi konsentrasi $10 \mathrm{nM}$, $100 \mathrm{nM}$, dan $1000 \mathrm{nM}$.

Setelah diberi perlakuan, telur diinkubasi dengan kelembaban relatif $60 \%$ selama 3 hari pada suhu $38,5^{\circ} \mathrm{C}$. Telur kemudian dimatikan dengan cara disimpan kedalam lemasi es 1 hari dengan suhu $4-5^{\circ} \mathrm{C}$ dan dibuka (umur 12 hari) kemudian isi telur dikeluarkan. Telur dibuka dengan cara menggunting cangkang telur menjadi 2 bagian dimulai dari cangkang yang terdekat dengan rongga udara, setelah itu membran korio alantois yang melekat pada cangkang dicuci dengan larutan isotonis $\mathrm{NaCl}$ 0,9\%. Langkah terakhir, membran korio alantois yang didapatkan diamati secara makroskopis. Hasil pengamatan makroskopik difoto dengan kamera. Datayang diperoleh berupa banyaknya pembuluh darah baru pada membran korio alantois setelah pemberian pinostrobin. Pembuluh darah yang dihitung adalah pumbuluh darah baru yang tumbuh dari percabangan pembuluh darah utama. Evaluasi uji angiogenik secara makroskopik dan mikroskopik. Pengamatanmakroskopik dilakukan dengan mengamati respon angiogenesis secara deskriptif dan kuantif kasi menggunakan metode West et $a{ }^{(7)}$ yaitu dengan menghitung jumlah pembuluh darah baru pada paper disc maupun disekeliling paper disc tersebut (setiap pembuluh darah baru yang terlihat di sekitar paper disc diberi nilai 1). Pengamatan mikroskopis pada kelompok perlakuan dilakukan dengan menambahkan antibodi VEGF pada CAM untuk melihat kemungkinan penghambatan angiogenesis dari pinostrobin melalui jalur pro angiogenik lain yaitu VEGF.

\section{HASIL DAN PEMBAHASAN}

\section{A. Ekstrak Temu Kunci}

Pemekatan ekstrak dilakukan dengan menggunakan rotary evaporator selama \pm 30 menit dengan kecepatan $60 \mathrm{rpm}$ pada suhu $50^{\circ} \mathrm{C}$. Bobot ekstrak kental etil asetat yang didapatkan 27,25 g. Nilai rendemen 
yang diperoleh adalah 6,81 \%, dielusi, yaitu fraksi yang memiliki sedangkan bobot ekstrak n-heksan spot yang terpisah dan tidak melebar yang didapat adalah $6,79 \mathrm{~g}$ dengan atau menumpuk serta yang paling nilai rendemen sebesar $1,69 \%$.

\section{B. Isolasi Pinostrobin}

Hasil fraksi yang diperoleh dielusi dan dipilih fraksi yang terbaik. Fraksi terbaik ditentukan berdasarkan prof I kromatogram yang tampak setelah mendekati standar pinostrobin. Setelah diisolasi, serbuk isolat yang didapat diidentif kasi menggunakan KLT densitomeri dengan pembanding standar pinostrobin (Sigma) (Gambar 1).

Tabel I. Hasil KLT Densitometri isolat vs standar punostrobin

\begin{tabular}{ccc}
\hline Peak & $\mathbf{R}_{\mathrm{f}}$ & $\lambda$ Maks $(\mathbf{n m})$ \\
\hline $\mathbf{1}$ & 0,76 & 298 \\
$\mathbf{2}$ & 0,74 & 299
\end{tabular}

Keterangan:

1 = isolat

2 = standar pinostrobin

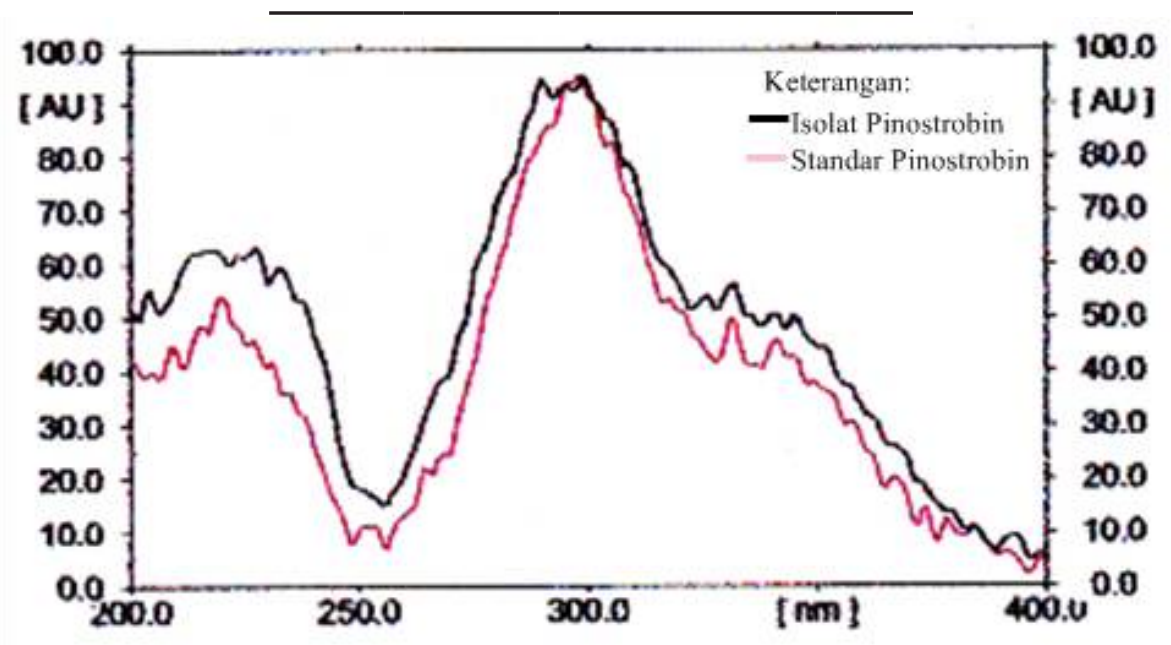

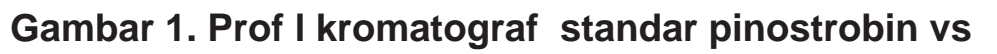
isolat pinostrobin menggunakan KLT Densitometri

C. Uji Efek Anti Angiogenesis pada CAM embrio ayam yang Hasil uji anti angiogenesis diinduksi bFGF. Hasil ini ditandai pinostrobin menunjukkan semakin dengan terjadinya penurunan jumlah tinggi kadar, semakin tinggi daya pembuluh darah baru yang tumbuh hambat angiogenesis yang terjadi pada kelompok perlakuan. 
Efek Anti Angiogenesis Temu Kunci....., Noor, Erma, Sitarina, Hady

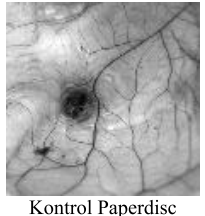

Kontrol Paperdisc

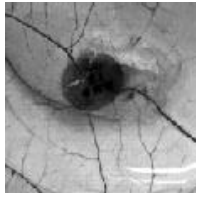

$\mathrm{N}-\mathrm{Heksan} 15 \mu \mathrm{g} / \mathrm{ml}$

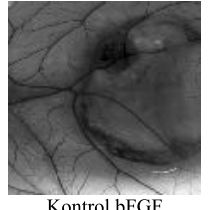

Kontrol bFGF

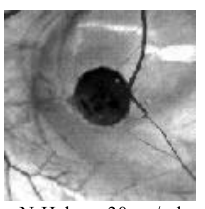

$\mathrm{N}-\mathrm{Heksan} 30 \mu \mathrm{g} / \mathrm{ml}$
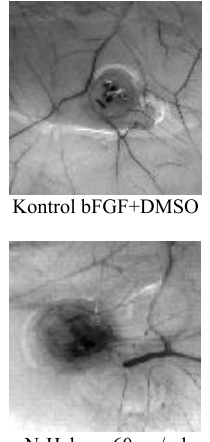

N-Heksan $60 \mu \mathrm{g} / \mathrm{ml}$

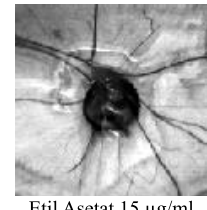

Etil Asetat $15 \mu \mathrm{g} / \mathrm{ml}$

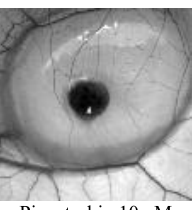

Pinostrobin $10 \mathrm{nM}$
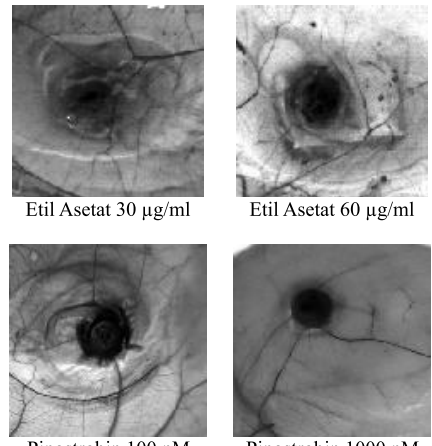

Gambar 2. Pengamatan makroskopis CAM pada masing-masing kelompok

Tabel 2. Jumlah pembuluh darah baru kelompok kontrol dan perlakuan

\begin{tabular}{|c|c|c|c|}
\hline K elompok Perlakuan & $\begin{array}{l}\text { J umlah } \\
\text { telur }\end{array}$ & $\begin{array}{c}\text { Jumlah Pembuluh } \\
\text { Darah Baru } \\
X \pm S D\end{array}$ & $\begin{array}{c}\text { Persen Penghambatan } \\
\text { A ngiogenesis } \\
X \pm S D\end{array}$ \\
\hline Kontrol paper disc & 5 & $28,50 \pm 2,35$ & 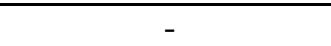 \\
\hline Kontrol bFGF & 5 & $40,70 \pm 2,56$ & - \\
\hline Kontrol bFGF + DM SO & 5 & $41,70 \pm 5,53$ & 0 \\
\hline $\mathrm{N}$-Heksan $15 \mu \mathrm{g} / \mathrm{ml}$ & 5 & $29,20 \pm 1,15$ & $29,98 \pm 2,76^{*}$ \\
\hline $\mathrm{N}-\mathrm{H}$ eksan $30 \mu \mathrm{g} / \mathrm{ml}$ & 5 & $17,30 \pm 1,35$ & $58,51 \pm 3,23^{*}$ \\
\hline $\mathrm{N}-\mathrm{H}$ eksan $60 \mu \mathrm{g} / \mathrm{ml}$ & 5 & $9,80 \pm 1,04$ & $76,50 \pm 2,49^{*}$ \\
\hline Etil asetat $15 \mu \mathrm{g} / \mathrm{ml}$ & 5 & $31,8 \pm 1,92$ & $23,74 \pm 4,61^{*}$ \\
\hline Etil asetat $30 \mu \mathrm{g} / \mathrm{ml}$ & 5 & $19,1 \pm 1,52$ & $54,20 \pm 3,64^{*}$ \\
\hline Etil asetat $60 \mu \mathrm{g} / \mathrm{ml}$ & 5 & $10,7 \pm 0,91$ & $74,34 \pm 2,18^{*}$ \\
\hline Pinostrobin $10 \mathrm{nM}$ & 5 & $33,10 \pm 2,61$ & $20,62 \pm 6,25^{*}$ \\
\hline Pinostrobin $100 \mathrm{nM}$ & 5 & $28,70 \pm 1,48$ & $31,18 \pm 3,56^{*}$ \\
\hline Pinostrobin $1000 \mathrm{nM}$ & 5 & $17,00 \pm 1,27$ & $59,23 \pm 3,06^{*}$ \\
\hline
\end{tabular}

Data terdistribusi normal

*)Hasil berbeda signifikan dengan kelompok kontrol bFGF + DM SO 0,8\%

Gambaran makroskopis kelompok kontroldanujidapatdilihatpadaGambar 2. Pengamatan makroskopis pada kelompok paper disc memperlihatkan hasil bahwa angiogenesis tetap terjadi baik disekitar paper disc maupun yang jauh dari letak paper disc. Hal ini menunjukkan bahwa paper disc yang digunakan tidak mempengaruhi proses angiogenesis CAM. Pada kelompok kontrol bFGF dapat terlihat pembentukan pembuluh darah baru dari pembuluh darah utama disekitar paper disc lebih banyak. Pemberian bFGF pada penelitian ini bertujuan untuk menginduksi terjadinya angiogenesis sebagaimana yang terjadipadakanker, sehinggaakanlebih 
mudah diketahui jalur penghambatan angiogenesis dari pinostrobin. Pada kelompok kontrol bFGF + DMSO 0,8 $\%$ menunjukkan hasil yang tidak jauh berbeda dengan kelompok kontrol bFGF. Analisis menggunakan Tukey menunjukkan nilai signif kansi antara kontrol bFGF dan kontrol bFGF + DMSO $0,8 \%$ adalah $0,999(p<0,05)$ sehingga dapat disimpulkan bahwa tidak ada perbedaan yang signif kan antara dua kelompok tersebut.

Gambaran

makroskopis kelompok uji sudah terlihat pada konsentrasi terkecil dari masingmasing kelompok uji. Pembuluh darah yang dihitung adalah pembuluh darah baru yang muncul disekitar pembuluh darah utama (ditunjukkan pada tanda panah $(\sqcap$ ) pada gambar 2). Perhitungasn prosentase penghambatan angiogenesis terdapat pada tabel II Hasil menunjujukkan bahwa konsentrasi penghambatan angiogenesis tertinggi kelompok ekstrak n-heksan dan etil asetat adalah pada konsentrasi $60 \mu \mathrm{g} / \mathrm{mL}$ sedangkan pada kelompok pinostrobin penghambatan angiogenesis tertinggi pada kelompok konsentrasi 1000 nM. Penggunaan bFGF sebagai penginduksiangiogenesismemberikan gambaran kemungkinan mekanisme anti angiogenesis dari pinostrobin adalah dengan menghambat bFGF sebagai faktor pro angiogenik.

Angiogenesis dapat membuat sel kanker menjadi lebih besar dengan cara membentuk pembuluh darah baru yang menyebabkan sel kanker mendapatkan suplai nutrisi dan makanan sehingga sel kanker akan terus berkembang dan $\operatorname{parah}^{(10)}$. Mekanisme angiogenesis ini diatur oleh faktor pro angiogenik dan anti angiogenik ${ }^{(8,10)}$

Basic fbroblast growth factor merupakan salah satu faktor pro angiogenik. bFGF berinteraksi dengan sel endotelial melalui reseptor tirosin kinase dan reseptor heparan sulfate proteoglycan dipermukaan sel. Kejadian tersebut dapat menyebabkan terjadinya pelepasan matriks pendegradasi membran basal (selama perkembangan embrio, cedera jaringan dan setelah transformasi sel ke fenotipe kanker) sehingga FGFs biologis akan menjadi aktif(11). Peran bFGF pada keadaan patologi kanker adalah untuk perkembangan sel kanker itu sendiri dan juga sebagai penginduksi pembuluh darah baru untuk mensuplai makanan dan nutrisi. Selain bFGF, masih banyak terdapat faktor pro angiogenik lain seperti endotel vaskular-derived growth factor (VEGF), angiopoetins, epidermal growth factor (EGF), interleukin 8 (IL-8), dan transforming growth factor

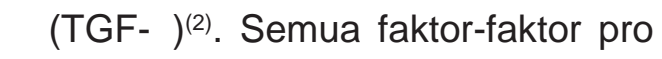
angiogenik ini akan menjadi berbahaya pada kondisi patologi kanker(12). Apabila terjadi penghambatan pembentukan pembuluh darah baru, maka pertumbuhan sel tumor maupun 
Efek Anti Angiogenesis Temu Kunci....., Noor, Erma, Sitarina, Hady

kanker akan terhambat karena tidak mendapatkan suplai nutrisi( ${ }^{(8)}$.

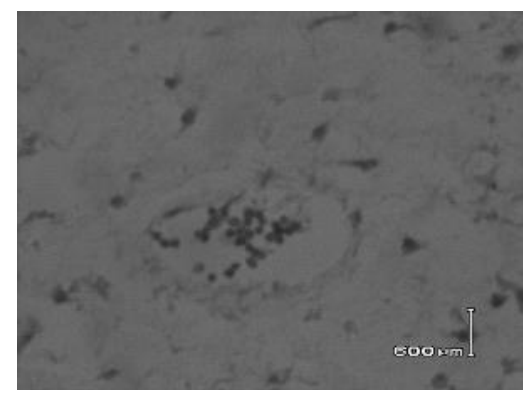

Kontrol bFGF +DMSO

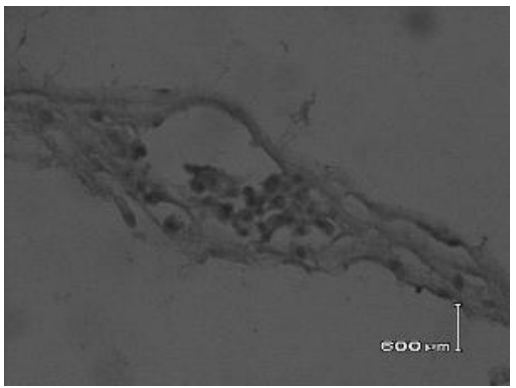

Kelompok uji ekstrak n-heksan

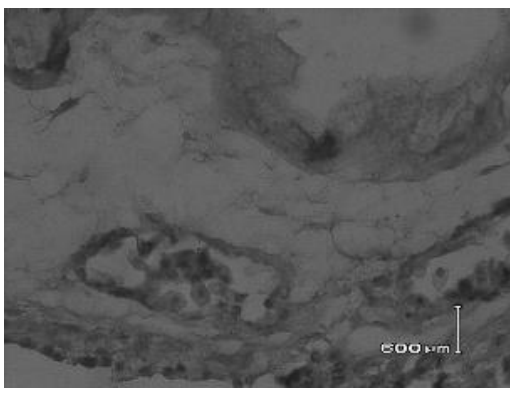

Kelompok uji ekstrak etil asetat

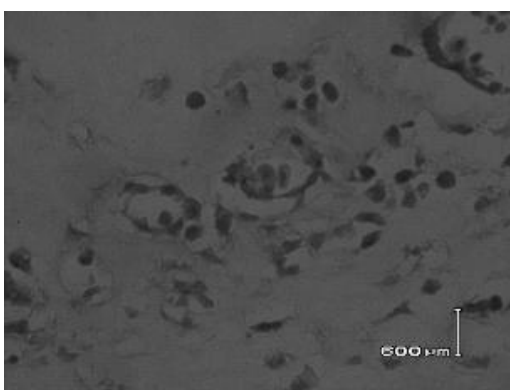

Kelompok uji isolat pi nostrobin

Gambar 3. Pengamatam mikroskopis CAM menggunakan antibodi VEGF
Hasil pengamatan mikroskopis manunjukkan adanya sel endotel dari pembuluh darah baru yang terekspresi VEGF pada kelompok ektrak etil asetat dan isolat pinostrobin, namun hal ini tidak terjadi pada kelompok ekstrak n-heksan (Gambar 3). Hasil ini dapat memberikan gambaran mekanisme anti angiogenesis dari ekstrak etil asetat dan isolat pinostrobin selaian melalui jalur penghambatan bFGF, juga melalui jalur penghambatan VEGF.

\section{KESIMPULAN DAN SARAN}

\section{Kesimpulan}

1. Ekstrak n-heksan, etil asetat dan isolat pinostrobin dari rimpang temu kunci (B. pandurata (Roxb.) Schlecht) memiliki efek anti angiogenesis pada membran korio alantois embrio ayam yang di induksi bFGF. Penggunaan bFGF sebagai penginduksi angiogenesis memberikan gambaran kemungkinan mekanisme anti angiogenesis dari masing-masing kelompok uji adalah dengan menghambat bFGF sebagai faktor pro angiogenik.

2. Pengamatan mikroskopis menggunakan antibodi VEGF menunjukkan bahwa ekstrak etil asetat dan isolat pinostrobin tidak hanya menghambat angiogenesis melalui penghambatan bFGF tetapi juga melalui penghambatan VEGF sebagai faktor pro angiogenik. 


\section{Saran}

Perlu dilakukan penelitian anti angiogenesis dari pinostrobin dengan menggunakan induksi faktor pro angiogenik lain untuk mengetahui jalur penghambatan angiogenesis yang lain dari pinostrobin.

\section{DAFTAR PUSTAKA}

Anonim, 2012, Report to the nation fnds continuing declines in cancer death rates since the early 1990s; Feature highlights cancers associated with excess weight and lack of suff cient physical activity, National Cancer Institute available at www.cancer. gov (diakses 5 Desember 2012)

Eichhorn, M.E., Kleespies A., Angele M.K., Jauch K.W., dan Bruns C.J., 2007, Angiogenesis in cancer: molecular mechanisms clinical impact, Langenbecks Arch Surg (2007) 392:371-379.

De Jong, W., 2001, Kanker, Apa itu? Pengobatan, Harapan Hidup dan Dukungan Keluarga, diterjemahkan oleh Astoeti Suharto H., Penerbit Arcan, Jakarta, 159-174.

Fahey, J.W., dan Stephenson, K.K., 2005, Pinostrobin from Honey and Thai Ginger (Boesenbergia pandurata): A Potent Flavonoid Inducer of Mammalian Phase 2 Chemoprotective and Antioxidant Enzymes, Department of Pharmacology and Molecular
Sciences, School of Medicine and Center forHuman Nutrition, Bloomberg School of Public Health, The Johns Hopkins University, Maryland 21205.

Smolarz, E., Mendyk, A., Bogucka dan J., Kocki, 2006, Pinostrobin-an anti-leukemic f avonoid from Polygonum lapathifolium L. ssp. nodosum (Pers.) Dans., Journal of Bioscience, Department of Pharmaceutical Botany, Medical University of Lublin, Lublin, 60(12):64-8.

Salamah,N., Sugiyanto, Hartati, M.S., Hayati, F., dan J. Pinus, 2009, Isolasi dan identif kasi eurycomanone akar pasak bumi (Eurycomalongifolia, Jack) serta uji anti-angiogenik, Majalah Farmasi Indonesia, 20(3), 118 - 126.

West, D.C., Thompson W.D., Sells P.G., and Burbridge M.F., 2001, Angiogenesis Protocols: Angiogenesis Assay Using Chick Chorioallantiocc Membrane, Editor by J.C. Murray, Humana Press Inc., New Jersey, 107129.

Medina, Patrick J., and Fausel, C., 2008, Pharmacotherapy, a Pathophysiologic Approach seventh edition: Cancer Treatment and Chemoterapy, Edited by DiPiro J.P, Talbert R.L., Yee G.C., Matzke G.R., Wells B.G., and Posey L.M., McGrawHill. London, 2085-2119. 
Efek Anti Angiogenesis Temu Kunci....., Noor, Erma, Sitarina, Hady

Balmer, C. Mc Manus, Valley Baird, Andrew, 2000, Angiogenesis in A.W., and Iannucci, A., Health and Disease: Fibroblast 2005, Pharmacotherapy, a Growth Factors and Their Pathophysiologic Approach sixth edition: Cancer Treatment and Chemoterapy, Edited by DiPiro J.P, Talbert R.L., Yee G.C., Matzke G.R., Wells B.G., and Posey L.M., McGraw-Hill, London, 2279-2328.

Receptor, Editor by Rubanyi G.M., Marcel Dekker Inc., USA, 75-88.

Auerbach, Robert, 2008, Angiogenesis An Integrative Approach From Science to Medicine: Models for Angiogenesis, Edited by Figg

Frisca, Sardjono, C.T., Sandra, W.D., Folkman, J., Springer F., 2009, ANGIOGENESIS: Patof siologi dan Aplikasi Klinis, Jurnal Kesehatan Masyarakat, (8): 174-187.

Science+Business Media LLC, New York, 299-312. 